THE Wabash CENTER

JOURNAL on TEACHING
BOOK REVIEW

\section{about Museums, Culture, and Justice to Explore in Your Classroom}

\author{
School: Questions Series
}

\section{Reviewed By}

Jody Washburn

Walla Walla University
Part of the School: Questions series edited by William Ayers, about Museums, Culture, and Justice provides a frank synopsis of the potential and shortcomings of museums in America, particularly as resources for educators creatively employing museum resources as tools for teaching justice. Beginning with a forthright discussion of the irony of museums being public resources, but not consistently accessible to, or representative of, the publics they serve, Therese Quinn provides a compelling short history of museums combined with brief deep dives into various aspects of the function, design, and use of museums.

As Kevin Kumashiro points out in his foreword, Quinn walks the reader through a nuanced engagement with museums demonstrating how students and educators can learn "from museums, even while remaking them" (xv). For example, citing Uncomfortable Art Tours led by art historian Alice Procter, Quinn calls educators to invite students to visit a museum and note things they might cite if they were to give an "unsettling" tour of the museum (35-36). Where might there be hidden histories or agendas? What labels are confusing? Who or what is left out? What could be done to improve the labels or selection of content? Espousing a collaborative approach that actively resists narrow, top-down authority, Quinn cites approaches such as community collaboration and team exhibit development as examples of how decision making can be intentionally shared leading to the empowerment of more diverse leaders and to more representative exhibits (30, 78).

In a brilliant modeling of the inclusive values and approaches she champions, Quinn describes ancient Babylonian princess Ennigaldi as the curator of the first “museum" almost 2600 years ago (11-12). Quinn also provides countless examples of exhibits and online resources featuring underrepresented community members. One particularly timely exhibit that moved me was Art and Healing: In the Moment, an exhibit at the Minnesota Institute of Art featuring space for reflection and artworks by various community members inspired by Philando Castile's life and tragic death (51). In the call to action threaded throughout her book, Quinn does not settle for telling educators to cite women and people of color and make space for members of the LGBTQ+ community or people with disabilities. Rather she fills her book with their voices, their projects and ideas, and countless examples of ways for educators, community leaders, and students to engage with multiple perspectives and continually make room at the table.

This book is a treasure chest for anyone invested in holistic pedagogy. I found numerous assignment ideas that I plan to integrate into an archaeology course I teach centered on the world of the Bible. While I have previously employed physical artifacts and multistage integrative assignments periodically in the course, I now have ideas for making almost every assignment collaborative, hands-on, and intentionally focused on traditionally minimized or ignored perspectives. The book's focus on museums makes it easily applicable to archaeology, but I would argue that the emphasis on justice throughout the book makes the principles, observations, and ideas for engagement adaptable to many religion and theology courses. 